\title{
PENGARUH PENDIDIKAN KESEHATAN METODE FOCUS GROUP DISCUSSION TERHADAP PENGETAHUAN SISWI TENTANG PERSIAPAN DALAM MENGHADAPI MENARCHE
}

\author{
Dwi Elka Fitri ${ }^{1 *}$, Epi Kurnia ${ }^{2}$ \\ Sekolah Tinggi Ilmu Kesehatan Pekanbaru Medical Center J1. Lembaga \\ Permasyarakatan No. 25 Gobah \\ e-mail: nersiwiek@gmail.com
}

Diterima : Oktober 2021, Diterbitkan : Desember 2021

\begin{abstract}
ABSTRAK
Menarche adalah menstruasi pertama kali yang terjadi pada masa awal remaja, hal tersebut terjadi sebagai bukti tanda menuju kedewasaan. Kesiapan mental yang baik dibutuhkan oleh anak yang akan mengalami menarche. Kurangnya pengetahuan tentang menstruasi dapat menyebabkan masalah kesehatan reproduksi. Banyak siswi yang belum memahami tentang menstruasi, oleh karena itu perlu dilakukan pendidikan kesehatan dengan metode yang tepat sehingga dapat meningkatkan pemahaman siswi. Metode Focus group discussion bagus untuk meningkatkan pengetahuan, karena dengan metode ini siswi dapat lebih paham secara mendalam melalui diskusi yang dilakukan. Penelitian ini bertujuan untuk mengetahui pengaruh pendidikan kesehatan dengan metode focus group discussion terhadap pengetahuan siswi tentang persiapan dalam menghadapi menarche. Penelitian ini merupakan penelitian kuantitatif dengan menggunakan desain penelitian Pre eksperimen design berupa rancangan "pretest-posttest with one gruop design. Populasi dalam penelitian ini yaitu siswi kelas IV, V, VI, di SDN 013 Desa Binabaru, dengan tekhnik sampling adalah total sampling yang berjumlah 53 responden. Untuk analisis bivariate, peneliti menggunakan uji pairesd sample T Test didapatkan nilai $p$ value pengetahuan $=0,000$ lebih kecil dari nilai alpha $(p<0,05)$, hal tersebut menunjukkan ada pengaruh pengetahuan siswi tentang persiapan menghadapi menarche sebelum dan setelah diberikan pendidikan kesehatan dengan metode Focus group discussion. Berdasarkan hasil penelitian ini, dapat dilakukan penelitian lebih lanjut dengan metode lain seperti metode bermain.

Kata Kunci : : Menarche, Pendidikan Kesehatan, Focus Group Discussion
\end{abstract}

ABSTRACT

Menarche is the first menstruation that occurs in early adolescence, it occurs as evidence of signs towards adulthood. Good mental readiness is needed by children who will experience menarche. Lack of knowledge about menstruation can cause reproductive health problems. Many students do not understand about menstruation, therefore it is necessary to carry out health education with the right method so that it can improve student understanding. The Focus group discussion method is good for increasing knowledge, because with this method students can understand more deeply through the discussions carried out. This study aims to determine the effect of health education with the focus group discussion method on students' knowledge about preparation for menarche. This research is a quantitative study using a pre-experimental research design in the form of a "pretest-posttest with one group design". The population in this study were students in grades IV, V, VI, at SDN 013 Binabaru Village, with a total sampling technique of 53 respondents. For bivariate analysis, the researcher used the paired sample T test, The $p$ value of knowledge $=0.000$ was smaller than the alpha value $(\mathrm{p}<0.05)$, it showed that there was an effect of students' knowledge about preparation for menarche before and after being given health education with the method Focus group discussions. Based on the results of this study, further research can be carried out with other methods such as the playing method.

Keywords $\quad$ :Menarche, Health Education, , Students, Focus Group Discussion 


\section{PENDAHULUAN}

Menarche adalah menstruasi yang pertama kali terjada ketika seseorang berada pada masa awal-awal. hal itu terjadi sebagai bukti atau tanda kedewasaan. Kedewasaan ini maksudnya ialah sudah terjadinya kematangan ovarium pada wanita. Ovarium yang sudah matang akan memiliki kemampuan untuk menghasilkan sel telur atau biasanya disebut dengan fase oosit (Lestari, 2015). Di Indonesia UndangUndang Kesehatan No.36 tahun 2009 pasal 136 mengatur tentang kesehatan reproduksi remaja. Pada pasal tersebut pemerintah diwajibkan untuk memastikan serta menjamin agar remaja mendapatkan informasi, layanan, serta edukasi terkait dengan kesehatan reproduksi agar mereka bisa mendapatkan kehidupan yang sehat serta bertanggung jawab (Kemenkes RI, 2015) dalam (Pramesti et al., 2019).

Menstruasi pertama pasti menjadi hal yang tidak mudah dihadapi oleh para remaja putri. Hal ini disebabkan oleh karena sebelumnya belum pernah mengalami menstruasi. Menarche dini yang dialami oleh remaja putri memiliki skor depresi yang lebih tinggi jika dibandingkan dengan remaja yang mengalami menarche terlambat (Bhanu \& Ramaswamy, 2018). Menurut Trepanier (2013) dalam (Dirgahayu, 2020) menarche yang lebih dini terjadi memiliki kerentanan terhadap gejala depresi dimana tekanan dari lingkungan menyebabkan terjadinya peningkatan rektivitas terhadap stressor pada masa remaja, ini kemudian menjadi periode penting dan kritis bagi kesehatan mental remaja dan harus dapat diberikan intervensi yang membuat Kesehatan mental tersebut tetap terjaga.

Populasi remaja memberikan kontribusi besar pada data demografi dunia. Di tahun 2018 WHO dalam dalam (Ratnasari \& Na'mah, 2019) telah mencatat bahwa seperlima penduduk dunia yang masuk kategori usia remaja yang berumur 12-16 tahun telah memasuki dan mengalami perubahan usia menarche. Sekitar 95\% wanita di Amerika Serikat telah menjukkan tandatanda pubertas dengan menarche para rentan usia 12-12,5 tahun yang ditandai dengan pertumbuhan fisik pada saat menarche. Data lain dari Riskesdas (2015) menunjukkan bahwa di provinsi Riau usia menarche remaja putri berada pada rentan usia 9-10 tahun sebanyak $1,5 \%$, usia 11-12 tahun sebanyak 20,8\%,13-14 tahun sebanyak 20,8\%, 13 14 tahun sebanyak 41,2\%, 15-16 tahun sebanyak 18,3\%,17-18 tahun sebanyak $1,4 \%$ dan usia 19-20 tahun sebanyak 0,3\% (Alhogbi, 2017).

Kesiapan mental dibutuhkan bagi anak atau remaja yang akan mengalami menstruasi pertama, dan untuk itu maka pengetahuan serta informasi tentang menstruasi pertama harus diberikan kepada mereka agar mereka siap menghadi menstruasi pertama (Suminar \& Anisa, 2020). Kurangnya Pendidikan menstruasi yang diberikan kepada anak dapat menyebabkan masalah kesehatan reproduksi dalam jangka panjang ketika siklus menstruasi datang. Beberapa diantaranya adalah terbukanya mulut rahim, keluarnya sel darah yang berisi protein melalui vagina dan inii kemudian dapat menjadi stimulus pertumbuhan kuman ketika tidak terjaganya kebersihan menstruasi. Hal tersebut juga dapat meningkatkan kesehatan seperti sistitis, infeksi, bahkan meningkatnya karsinoma serviks (Febrina, 2020).

Berdasarkan telaah penelitian terdahulu serta latar belakang yang telah diuraikan di atas, penelitian ini mengangkat rumusan masalah terkait pengaruh pendidikan kesehatan dengan metode focus group disscosion terhadap pengetahuan siswi kelas IV, V, VI tentang persiapan dalam menghadapi 
menarche di SDN 013 Desa Bina Baru Kec. Kampar Kiri Tengah".

\section{METODE PENELITIAN}

Penelitian ini merupakan penelitian kuantitatif dengan menggunakan desain penelitian Pre eksperimen design berupa rancangan "pretest-posttest with one gruop design".(Sugiyono, 2016)

Pada penelitian ini yang menjadi populasi dan subjek penelitian adalah siswi dari kelas IV, V, dan VI di SDN 013 Desa Binabaru Kec. Kampar Kiri Tengah yang belum mengalami Menarche dengan jumlah 53 siswi teknik sampling yang digunakan dalam penelitian ini adalah total sampling dengan responden yang memenuhi kriteria kriteria inklusi (Arikunto, 2012).

Analisa data yang digunakan dalam penelitian ini adalah analisa univariat dan bivariat. Analisa univariat pada penelitian ini adalah tentang karakteristik responden pada penelitian ini seperti umur. Sedangkan untuk analisa bivariat menggunakan pengujian Paired sample $T$ test. Analisa bivariat ini dilakukan untuk megetahui pengaruh pendidikan kesehatan tentang menarche. Hasil penelitian ini dikatakan berpengaruh apabila menunjukkan hasil nila $p$-value $\leq 0,05$ dan tidak berpengaruh apabila p- value $>0,05$.

\section{HASIL DAN PEMBEHASAN}

Pada penelitian ini akan diurutkan hasil penelitian mengenai pengetahuan responden sebelum dan sesudah dilakukan pendidikan kesehatan dengan metode focus group discussion.

\section{a. Hasil Univariat}

Berdasarkan penelitian tentang Pengaruh Pendidikan Kesehatan Terhadap Pengetahuan Siswi Kelas IV, V, Dan VI tentang Menarche dengan Metode Focus Group Disscosion pada tanggal 28 April 2021 didapatkan hasil sebagai berikut :

\section{Karakteristik Berdasarkan Usia \\ Responden}

Tabel 1. Distribusi Frekuensi Usia Responden Di SDN 013 Desa Bina Baru

Kec. Kampar Kiri Tengah.

\begin{tabular}{lll}
\hline Usia & Frekuensi & Persentase (\%) \\
\hline 10 Tahun & 10 & 18,9 \\
11 Tahun & 18 & 34,0 \\
12 Tahun & 21 & 39,6 \\
13 Tahun & 4 & 7,5 \\
\hline Total & $\mathbf{5 3}$ & $\mathbf{1 0 0}$ \\
\hline
\end{tabular}

Dari tabel di atas menunjukkan bahwa responden terbanyak berusia 12 tahun yaitu 21 orang $(39,6 \%)$, usia 11 tahun sebanyak 18 orang $(34,0 \%)$, usia 10 tahun sebanyak 10 orang $(18,9 \%)$ dan usia 13 sebanyak 4 orang (7,5\%).

\section{Karakteristik Responden Berdasarkan Kelas}

Tabel 2. Distribusi Frekuensi Kelas Responden Di SDN 013 Desa Binabaru Kec. Kampar Kiri Tengah

\begin{tabular}{lll}
\hline Kelas & Frekuensi & $\begin{array}{l}\text { Persentase } \\
(\boldsymbol{\%})\end{array}$ \\
\hline IV & 16 & 30,2 \\
\hline V & 19 & 35,8 \\
\hline VI & 18 & 34,0 \\
\hline Total & $\mathbf{5 3}$ & $\mathbf{1 0 0}$ \\
\hline
\end{tabular}

Dari tabel di atas menunjukkan bahwa responden terbanyak adalah kelas V sebanyak 19 orang, Kelas VI 18 orang dan kelas IV sebanyak 16 orang.

\section{Tingkat Pengetahuan Sebelum (Pre-test)}

Tabel 3. Nilai meanPengetahuan

Sebelum Diberikan Pendidikan Kesehatan

\begin{tabular}{lll}
\hline Kategori & Frekuensi & $\begin{array}{l}\text { Persentas } \\
\text { e \% }\end{array}$ \\
\hline Baik & 11 & $20,8 \%$ \\
Cukup & 14 & $26,4 \%$ \\
Kurang & 28 & $52,8 \%$ \\
\hline Total & $\mathbf{5 3}$ & $\mathbf{1 0 0 \%}$ \\
\hline
\end{tabular}

Dari tabel di atas menunjukkan bahwa sebagian besar responden 


\section{memiliki tingkat pengetahuan kurang baik sebelum diberikan pendidikan kesehatan sebanyak 28 orang $(52,8 \%)$. \\ 4. Nilai mean Pengetahuan Sesudah (Post-test)}

Tabel 4. Hasil Kuesioner Pengetahuan

Sesudah Diberikan Pendidikan

Kesehatan dengan metode FGD

\begin{tabular}{lll}
\hline Kategori & Frekuensi & $\begin{array}{l}\text { Persentase } \\
\mathbf{\%}\end{array}$ \\
\hline Baik & 53 & $100 \%$ \\
Cukup & 0 & $0 \%$ \\
Kurang & 0 & $0 \%$ \\
\hline Total & $\mathbf{5 3}$ & $\mathbf{1 0 0 \%}$ \\
\hline
\end{tabular}

Dari tabel di atas menunjukkan bahwa hasil pengetahuan 53 responden sesudah diberikan pendidikan kesehatan, seluruh pengetahuan responden baik sebanyak 53 orang (100\%).

\section{Hasil Bivariat}

Tabel 5. Perbedaan Pengetahuan Sebelum (Pre-Test) dan sesudah (PostTest) Dilakukan Pendidikan Kesehatan

\begin{tabular}{lccc}
\hline & $\mathrm{F}$ & $\%$ & $P$ Value \\
\cline { 1 - 3 } Pre Tes & 53 & 56,75 & 0,000 \\
\cline { 1 - 2 } Pos Tes & 53 & 82,04 & \\
\hline
\end{tabular}

Analisa bivariat digunakan untuk melihat perubahan pengetahuan menarche sebelum (pre-test) dan sesudah (post-test) dilakukan pendidikan kesehatan tentang menarche. Hasil penelitian ini dikatakan berpengaruh apabila menunjukkan hasil $\mathrm{p}$ value $\leq$ 0,05 . Pengolahan data dalam penelitian menggunakan uji wilcoxon signed ranks test karena data pada penelitian ini adalah data nonparametrik yang memiliki skala ukur ordinal. Berdasarkan hasil pengolahan data dengan menggunakan program SPSS (Statiscal Program For Social Science) diperoleh hasil sebagai berikut:

Dari tabel diatas menunjukkan hasil bahwa sebanyak 28 orang $(52,8 \%)$ memiliki pengetahuan tentang menarche yang masih dalam kategori kurang baik dan setelah dilakukan pendidikan kesehatan tentang menarche jumlah responden secara keseluruhan telah memiliki pengetahuan dalam kategori baik yaitu sebanyak 53 orang (100\%).

Berdasarkan Hasil Uji Paired sample $T$ test diperoleh $\mathrm{p}$ value $=0,000$ yang lebih kecil daripada nilai alpha ( $\mathrm{p}$ $0,05)$ didapatkan perbedaan yang signifikan antara pengetahuan sebelum dan sesudah dilakukan pendidikan kesehatan tentang menarche.

Analisa data univariat digunakan untuk memberikan gambaran karakteristik responden yaitu, usia, kelas, pengetahuan sebelum (pre-test) dan dan setelah (post-test) dilakukan pendidikan kesehatan tentang menarche. Sedangkan analisa bivariat digunakan untuk menelaah pengaruh pendidikan kesehatan dengan metode Focus Group Disscussion terhadap pengetahuan siswi kelas IV, V, dan VI tentang menarche.

Berdasarkan data yang diperoleh dari 53 responden, di dapatkan sebagian besar siswi SDN 013 Binabaru berumur 10 tahun sebanyak 10 responden $(18,9 \%)$, umur 11 sebanyak 18 responden $(34,0 \%)$, umur 12 tahun sebanyak 21 responden $(39,6 \%)$ dan umur 13 tahun sebanyak 4 responden $(7,5 \%)$.

Menurut Dahlandjawad (2014) pada usia 10-13 tahun seseorang telah memasuki perkembangan dimana ia mampu berpikir secara logis, masuk akal, serta memiliki kemampuan untuk menerima sudut pandang yang berbeda dari orang lain.

Sukmawati (2016) menjelaskan bahwa pada usia awal remaja atau pubertas, perkembangan fisik seorang wanita ditandai dengan membesarnya payudaya, munculnya jerawat, tumbuhnya rambut di ketiakt dan sekitar alat kelamin, serta datangnya menstruasi 
pertama (menarche). Pada fase ini, perlu adanya pendampingan dan Pendidikan kesehatan reproduksi untuk remaja putri khususnya mengenai menarche, sehingga mereka mendapatkan pengetahuan yang dapat memberikan arahan bagaimana seharusnya mengambil tindakan atas kesehatan mereka.

Sesuai hasil penelitian didapatkan bahwa ketika usia seseorang bertambah maka terjadi peningkatan pengetahuan dan wawasan dalam pendidikan formalnya maupun pengetahuan dan wawasan diluar pendidikannya. Lianawati (2012) menguatkan dengan menjelaskan bahwa usia seseorang memberikan pengaruh terhadap daya tangkap dan pola pikir seseorang.

Melalui pendidikan kesehatan, terjadi sebuah upaya membuka peluang bagi setiap orang untuk terus menerus meningkatkan kesadaran literasi kesehatan demi peningkatan pengetahuan serta keterampilan seseorang dalam menjaga kesehatannya (Nursalam, 2014).

Dalam penelitian ini peneliti mendapati bahwa usia seseorang memberikan pengaruh terhadap pola pikir dan pengetahuannya. Usia seseorang yang semakin bertambah memberikan pengaruh pada semakin meningkatnya kemampuan dalam menerima informasi baik melalui media tulis, visual, dan media lainnya.

Berdasarkan karakteristik kelas, yang menjadi responden adalah siswi kelas IV, V dan VI SDN 013 Desa Binabaru Kec. Kampar Kiri Tengah. Hasil penelitian menunjukan bahwa menstruasi belum dialami oleh sebagian responden yaitu dari kelas IV sebanyak 16 orang $(30,2 \%)$, kelas V sebanyak 19 orang $(33,8 \%)$, dan kelas VI sebanyak 18 orang $(34,0 \%)$.

Menurut Margono (2012) pengetahuan dan informasi yang kurang mengenai kesehatan reproduksi, dalam hal ini adalah menarche, tidak hanya memberikan dampak pada kseehatan menstruasi saja, namun juga disertai dengan munculnya perilaku negative dari para siswi sekolah dasar seperti sentuhan pada bagian tubuh yang sensitif hingga berpelukan. Hal tersebut menggambarkan bahwa perlu adanya Pendidikan kesehatan reproduksi kepada para siswi sejak usia sekolah dasar.

Peneliti mendapati bahwa ketika para siswi memasuki tingkat pendidikan yang lebih lanjut maka pengetahuan dan kesadaran akan pentingnya kesehatan semakin bertambah dan berkembang, sehingga ia akan lebih berhati-hati dalam melakukan suatu tindakan demi menjaga kesehatannya.

Berdasarkan data yang diperoleh dari 53 responden yang ada di SDN 013 Desa Binabaru sebelum di berikan pendidikan kesehatan melalui Metode focus Gruop discussion didapatkan bahwa sebanyak 28 responden $(52,8 \%)$ masih memiliki pengetahuan yang kurang baik, 14 responden $(26,4 \%)$ memiliki pengetahuan yang cukup, dan hanya 11 responden $(20,8 \%)$ yang memiliki tingkat pengetahuan baik.

Temuan diatas sejalan dengan hasil penelitian Sukmawati (2016) yang berjudul "Pengaruh Pendidikan Kesehatan Tentang Menarche Terhadap Tingkat Pengetahuan Tentang Menarche Pada Siswi Kelas V dan VI Di SD Negeri 01 Binangun Kabupaten Cilacap" dengan hasil bahwa responden yang memiliki tingkat pengetahuan kurang baik 10 responden $(22,7 \%), 21$ responden $(47,7 \%)$ denggan pengetahuan cukup, dan 13 responden $(29,5 \%)$ pada tingkat pengetahuan yang baik.

Temuan peneliti dalam penelitian ini responden yang belum diberikan 
edukasi tentang persiapan dalam menghadapi menarche memiliki tingkat pengetahuan kurang baik. Hal ini disebabkan karena kurangnya informasi tentang kesehatan reproduksi khususnya tentang menarche. Sehingga pada saat dilakukan penilaian tingkat pengetahuan sebelum diberikan edukasi jumlah responden dengan tingkat pengetahuan kurang baik menjadi banyak.

Berdasarkan data yang diperoleh dari 53 responden yang ada di SDN 013 Desa Binabaru setelah diberikan pendidikan kesehatan melalui metode Focus Gruop Discussion didapatkan bahwa seluruh responden telah berada pada tingkat pengetahuan baik dengan total 53 responden $(100,0 \%)$.

Temuan diatas sejalan dengan hasil penelitan Karmila (2018) yang berjudul "Pengaruh Kesehatan Dengan Metode Ceramah Terhadap Menarche Pada Remaja Putri Kelas V Di SDN Cibiru 3 Bandung" dengan hasil bahwa responden setelah diberikan pendidikan kesehatan memiliki tingkat pengetahuan baik sebanyak 33 responden 78,6\%, cukup sebanyak 8 responden $(19,0 \%)$ dan kurang baik sebanyak 1 responden $(2,4 \%)$.

Temuan peneliti dalam penelitian ini adalah responden memiliki perubahan tingkat pengetahuan setelah diberikan edukasi tentang pengenalan tentang menarche dan cara menanganinya pada saat mangalami menarche (menstruasi pertama).

Berdasarkan hasil dari uji paired sample $T$ test test didapatkan adanya pengaruh signifikan terhadap pengetahuan responden sebelum dan sesudah diberikan pendidikan kesehatan tentang menarche dimana $P$ value pengetahuan $=0,000$ lebih kecil dari pada nilai alpha $(\mathrm{P}<0,05)$. Didapatkan adanya perbedaaan signifikan terhadap pengetahuan pengetahuan responden sebelum dan sesudah diberikan pendidikan kesehatan tentang menarche. Dapat disimpulkan bahwa adanya pengaruh pendidikan kesehatan dengan metode Focus Group Disscussion terhadap pengetahuan siswi kelas IV, V, dan VI tentang persiapan dalam menghadapi menarche di SDN 013 Desa Binabaru Kec. Kampar Kiri Tengah.

Selain itu metode focus group discussion memiliki banyak kelebihan yaitu terhimpunnya informasi, ide, dan pandangan yang luas dari satu kelompok karena adanya sinergisme. Diskusi kelompok juga menjadi stimulan bagi para peserta agar merasakan suasana yang menyenangkan sehingga mampu memberikan dorongan kepada peserta untuk berpartisipasi dan memberikan pendapat.

Penggunaan metode yang tepat dalam penelitian ini telah mampu memberikan pengetahuan kepada responden dalam fokus Group Discussion penelitian ini. Seperti dijelaskan oleh Mulyana (2005) dikutip dalam penelitian Pulungan (2007) menjelaskan bahwa metode yang tepat memberikan pengaruh pada tingkat keberhasilan dalam menyampaikan pesan dan makna yang terkandung dalamnya dalamnya.

Temuan peneliti dalam penelitian ini menyatakan bahwa pendidikan kesehatan tentang menarche dengan metode focus group discussion merupakan intervensi yang baik untuk meningkatkan pengetahuan responden tentang menarche. Selain itu edukasi yang diberikan akan memberikan pemahaman responden bahwa pentingnya dalam meningkatkan kulitas hidup yang baik

\section{KESIMPULAN}

Berdasarkan hasil penelitian tentang "Pengaruh Pendidikan Kesehatan Dengan Metode Focus Group Disscussion Terhadap Pengetahuan 
Siswi Kelas IV, V, dan VI Tentang Persiapan Dalam Menghadapi Menarche" yang dilakukan kepada 53 responden di SD Negeri 013 Desa Binabaru Kec. Kampar Kiri Tengah, dapat disumpulkan bahwa ada pengaruh yang signifikan antara pengetahuan sebelum dan sesudah diberikan pendidikan kesehatan tentang menarche dengan metode Focus Group Disscussion dimana nilai $p$ value pengetahuan $=0,000$ kecil dari nilai Alpha $(P<0,05)$.

\section{UCAPAN TERIMAKASIH}

Penulis mengucapkan terima kasih yang sebesar-besarnya kepada:

- Prof. Dr. H. K. Suheimi, SPOG, K. (Fer) selaku Ketua STIKes PMC Pekanbaru.

- Seluruh pihak di SDN 013 Desa Binabaru, Kampar Kiri Tengah.

- Seluruh keluarga dan teman yang telah memberikan dukungan untuk menyelesaikan penelitian ini.

\section{DAFTAR PUSTAKA}

Alhogbi, B. G. (2017). Hubungan Keterpaparan Media Massa Terhadap Usia Menarche Pada Siswi Di SMP Negeri 2 Bangko Bagasiapiapi. Journal of Chemical Information and Modeling, 53(9), 21-25.

Arikunto, S. (2013). Prosedur Penelitian: Suatu Pendekatan Praktik. Jakarta:Rineka Cipta

Bhanu, B. M., \& Ramaswamy. (2018). Assessment of depression among adolescent girls with early and late menarche-influence of area and socio-economic status. International Journal of Psychology and Psychiatry, 6(2), 76.

Dirgahayu, J. K. (2020). Literature Review: Pengaruh Pendidikan Kesehatan Menggunakan Media Audiovisual Tentang Menarche Terhadap Kesiapan Siswi SD. 2, 13-22.

Febrina, R. (2020). Edukasi Menstruasi pada Remaja Putri di Pondok Pesantren Darussalam Al-Hafidz Kota Jambi.
Jurnal Abdimas Kesehatan (JAK), 2(3), 201.

Karmila, W., Yani, F., Mulyati, T., \& Jamiyanti, (2018). Terhadap Pengetahuan TentangMenarche Pada Remaja Putri Kelas V DI SD Negeri Cibiru 3.

Lestari, T. 2015. Kumpulan Teori Untuk Kajian Pustaka Penelitian Kesehatan. Medical Book, Yogyakarta.

Lianawati, Iss. (2012). Tingkat Pengetahuan Remaja Putri Tentang Personal Hygiene Saat Menstruasi Pada Siswi Kelas X SMA Islam Terpadu AlMasyhur Pati Tahun 2012. Sekolah Tinggi Ilmu Kesehatan Kusuma Husada. Surakarta.

Margono. (2012). Materi kespro Diberikan Sejak SD, Mengapa Tidak.http://www.kulonprogokab.go .id/v21/Materi-Kespro-DiberikanSejak-SD-Diakses tanggal 26 Juli 2021.

Nursalam. (2014). Manajemen keperawatan aplikasi dalam praktik keperawatan profesional edisi 4. Jakarta : Salemba Medika.

Pulungan. (2007). Pengaruh Metode Penyuluhan Terhadap Peningkatan Pengetahuan dan Sikap Dokter Kecil Dalam Pemberantasan Sarang Nyamuk Demam Berdarah Dengue (PSN DBD) Di Kecamatan Helvetia. Tesis. Ilmu Kesehatan Masyarakat USU Medan.

Pramesti, H. D., Suherni, \& Nur, D. (2019). Perbedaan Peningkatan Pengetahuan Menstrual Hygiene Menggunakan Media Booklet dan Leaflet pada Remaja Putri di Pondok Pesantren An-Nur Bantul.

Ratnasari, D., \& Na'mah, L. U. (2019). Peer education untuk meningkatkan pengetahuan remaja putri umur $10-12$ tahun tentang menarche dengan media ular tangga di desa sidoharum sempor kebumen. Proceeding of TURECOL.

Riskesdas. 2015. Perkembangan StatusKesehatan Masyarakat 
Indonesia.http://digilib.unimus.ac.id/down load.phpid=13019, diakses pada tanggal 12 maret 2021

Suminar, T, I, \& Anisa, D. (2020). Pengaruh Pendidikan Teman Sebaya (Peer Education) Kesehatan Menstruasi Terhadap Kesiapan Siswi Sd Menghadapi Menstruasi Awal. Jurnal Kesehatan Kusuma Husada, 16, 132141.

Sukmawati, E., Imah, N. D. N., \& Sulistyoningrum, I. (2016). pengaruh pendidikan kesehatan tentang menarche terhadap tingkat pengetahuan tentang menarche pada siswi kelas V dan VI. 2TRIK: Tunas-Tunas Riset Kesehatan, VI(4), 173-180.

Sugiyono, (2009).Metode Penelitian Kuantitatif, Kualitatif dan $R \& D$, Bandung Alfabet 